\title{
CSOKOLÁDÉN INNEN ÉS TÚL - FÓKUSZCSOPORTOS VIZSGÁLAT A 8-14 ÉVES FIATALOK KÖRÉBEN
}

\author{
Lendvai Edina - Forró Felícia
}

\begin{abstract}
Absztrakt: Napjainkban kiemelt szerepet kap az egészséges életmód, az egészséges táplálkozás, a testmozgás fontossága, mégis a letöbb reklám a kalóriadús, nagy cukortartalmú élelmiszerekkel bombázza a társadalmat. A színes, humoros, érzelemdús, érdekes reklámok elősorban a fiatalokat, gyerekeket célozzák meg. Kutatásunkban arra szerettünk volna választ kapni, mennyire befolyásolják a reklámok a diákokat, fiatalokat a csokoládék fogyasztásában, milyen szerintük a jó csokoládé reklám, illetve az édesség fogyasztási szokásaik és a reklámok közötti összefüggések feltárására kerestük a válaszokat. Vizsgálati módszerként fókuszcsoportos felmérést alkalmaztunk, 2019-ben. Az eredmények azt mutatják, hogy a jelenlegi reklámok nem befolyásolják a fiatalok csokoládé vásárlási, illetve fogyasztási szokásait. Úgy gondoljuk, a hatékonyság növelése érdekében a vizsgált korosztály igényeit, ötleteit figyelembe véve kellene a reklámokat elkészíteni.
\end{abstract}

\begin{abstract}
Nowadays healthy lifestyle, eating healthily and taking exercise are of overriding importance nevertheless most commercials bombard society with foodstuffs which are rich in calories and contain much sugar. The colourful, humorous, emotional, interesting commercials aim mostly the young and children. In our research we wished to find the answer to that how much commercials influence the young and the students in consuming chocolate and according to them what a good chocolate commercial is like and we searched for the answers on revealing the connection between sweet-consuming habits and commercials. As a method of examination, we applied enquiry with a focus-group. The results of examination showed that recent commercials do not really affect chocolate-purchasing and consuming habits of young. In our view commercials should be made more effective regarding the studied age group's demands and ideas.
\end{abstract}

Kulcsszavak: csokoládé, reklám, fókuszcsoport, gyerekek

Keywords: chocolate, commercial, focus group, children

\section{Bevezetés}

„Eladó az egész világ” idézzük sokszor Goethe Faustját. S talán, ha mindent nem, de, valóban rengeteg dolgot megkaphatunk a pénzünkért cserébe.

A reklámok - ha akarjuk, ha nem - behálózzák az életünket. Sokan tudatosan próbálják elkerülni őket, de vajon a gyerekek tudnak-e ellene tenni valamit. A reklámkészítők jól tudják, hogy ez a korosztály a legbefolyásolhatóbb, ezért nagyon sok reklám öket célozza meg. Kutatások szerint a gyermekek, a fiatalok - 13 és 29 év között - napi szinten átlagosan 220 percet töltenek a televízió előtt, míg körülbelül 120 percet internetezéssel, tehát ezeken az eszközökön keresztül a legkönnyebb rájuk nyomást gyakorolni. (www.origo.hu, hogyanmondjamelneked.hu).

A gyermekek életében fontos szerepet töltenek be az édességek, akár jutalom, akár édes kívánság, vagy mintegy tiltott gyümölcs formájában.

E fenti két dolgot összekapcsolva végeztük el kutatásunkat, melynek során az édességeket, csokoládékat ajánló reklámokat vettük górcső alá, illetve azt, hogy az általános iskolások hogyan élik meg ezen termékek fogyasztását, milyennek látják a reklámokat, ismerik-e a szlogeneket. 


\subsection{Csokoládé meghatározása, története, elterjedése}

A csokoládé egy édesipari termék, amely Amerika trópusi területein őshonos, kisméretü örökzöld növény, a kakaófa (Theobroma cacao) toktermésének a magjából, a kakaóbabból készül. A kakaófák, melyek 4-8 méter magasra is nőhetnek, átlagosan a 3-4. évben fordulnak termöre és körülbelül 50 évig képesek termést hozni. Az általában 15-30 centiméter nagyságú és sárgás-barna színű termésben 2050 darab mandula alakú mag található. A kakaófa gyümölcseit évente kétszer, ősszel és tavasszal szüretelik. 3 fő kakaóbab fajtát különböztethetünk meg; a Criollo-t, a Trinitario-t és a Forastero-t, amelyek közül az utóbbi nagy népszerüségnek örvend, ugyanis a világ kakaótermésének 80\%-át adja. A kakaóbabszemek jelentős része 40$50 \%$ zsiradék, ami a szintén értékes kakaóvaj. A kakaó legfóbb hatóanyaga a theobromine, melynek összetétele hasonló a koffeinhez (Filep-Pinczel 2016).

A csokoládé története a Kr. u. 600-as évekre nyúlik vissza. A maják nagy becsben tartották a kakaóbabot, ugyanis szertartásokon, kereskedelmi, konyhai és orvosi célokra is használták. Az istenek eledelének is nevezett kakaóbabot megpörkölték, majd chilivel és kukoricával ízesítve vízzel felöntve fogyasztották. Későbbiekben már vaníliát, mézet és egyéb növényeket is felhasználtak a forrón fogyasztott habos nedü készítéséhez. Az italt a nők készítették, de kizárólag férfiak fogyaszthatták, mivel túl erősnek és mérgezőnek találták a gyermekek és a gyengébbik nem számára.

Az aztékoknál is fontos szerepet töltött be a kakaó. A majákhoz hasonlóan szertartások, ünnepek, különleges események alkalmával fogyasztották és pénzügyi eszközként is szolgált. A kakaóbabot térdükön törték meg majd megpörkölték füszerezték és végül leszürték. A majákkal ellenben az aztékok hidegen itták (Gyimes-Szabó, 2008). Vaníliával ízesítették (Kovács et al., 2011).

A kakaóbab nem sokáig maradt spanyol földön, a 17. század elején meghódította Hollandiát, Nagy-Britanniát és Franciaországot is. A holland kakaópor Conraad Van Houten nevéhez füződik, aki 1828-ban megalkotott egy olyan gépezetet, prést, amely a kakaómasszából kisajtolt kakaóvaj zsírtartalmát felére csökkentette. A préselt terméket porrá őrölték és így kapták a kakaóport (Filep-Pinczel, 2016). A 19. század elején Quaker John Cadbury kávé kakaó és tea árusításával foglalkozott, majd csokoládégyártásba kezdett. Az első táblás csokoládé Joseph Fry, angol kvéker kísérletezéseinek köszönhetö, aki olyan elegyet hozott létre, amely masszává keverve jól formázható. A század végére Daniel Peters megalkotta a mai napig közkedvelt tejcsokoládét (Coady, 2008).

Magyarországon Stühmer Frigyes több mint 150 éve alapította meg az első csokoládégyárát, amely olyan nagymértékü fejlödésen ment keresztül, hogy 1883-ra már gőzzel hajtott gépek segítségével készültek a finomságok. A kiváló minőségnek köszönhetően felvette a versenyt az osztrák és svájci csokoládékkal is. Az alapító halála után családja vitte tovább a vállalkozást. 2005 óta a Stühmer Kft. gyártja a prémium minőségü csokoládékat, amely azóta folyamatosan fejlődik és terjeszkedik (www.stuhmer.hu).

A szerencsi csokoládégyár, ahol a jól ismert „cicás” kakaóport is gyártják 1923ban kezdte meg müködését 50 fővel. Napjainkban a családi vállalkozásként 150 
fővel, Szerencsi Bonbon Kft. néven viszi tovább a magyar csokoládé hírnevét a vállalat a világban (www.szerencsibonbon.hu, 2019).

1868-ban egy német cukrászmester megalapította országunk legnagyobb csokoládégyárát Pesten, melyet az alapító halála után az örökösei 1928-ban modernizáltak, így cégük részvénytársasággá alakult, melyet a II. világháború után államosítottak és beolvasztották a Magyar Édesipari Vállalatba. Az 1992-es privatizáció után német tulajdonos kezébe kerül a cég, amely 2004-től már a jól ismert Bonbonetti Csoport néven folytatta a munkát (www.bonbonetti.hu).

\subsection{Reklám-hatás és vizsgálatai}

Egy reklám lehet jó vagy rossz, hosszú vagy rövid, figyelemfelhívó vagy unalmas, de egy biztosan igaz: hatnak ránk, emberekre. A reklámok általános célja, hogy valakire vagy valamire felhívja a figyelmet, tájékoztasson, érzelmeket váltson ki, vásárlásra szolgáltatás igénybevételére ösztönözzön.

Egy átlagos fogyasztót naponta több ezer hatás ér, ezek közé tartoznak a reklámok is. Az ingerek közül a fogyasztó sajátos szelekció-mechanizmus segítségével választ (Bauer et al., 2014).

A reklámhatás azt fejezi ki, hogy a kommunikációs tevékenység milyen mértékben érte el a vállalat által kitüzött célt (ez lehet ismertség növelése, márkaépítés). A reklámhatás-vizsgálatok elsősorban a felidézést, az üzenet megértését, valamint a fogyasztói/vásárlási magatartásra gyakorolt hatást kutatják marketingkutatás során (Agárdi, 2010).

Különböző kísérleteket, kutatásokat végeztek a minél hatásosabb reklámok elöállítására, amelyekkel üzenetet közvetítenek a közönség felé. Fontos, hogy legyen lélektani hatása, hogy felkeltse a figyelmet, növelje az emlékezést, szükségleteket, vágyakat teremtsen és megszerettesse a reklámozót a közönséggel. Kutatásokban azt tapasztalták, hogy 4-5 éves kor alatt a gyerekek nem tudnak különbséget tenni a müsorfolyamban megjelenő hirdetések és a müsorok között, azonban 3-4 éves korban befolyásolhatóak a leginkább. A szakember megállapította, hogy az öt év felettiek már felismerik a hirdetést, elsősorban a tulajdonságaik alapján, pl. időtartam, humorosság. Körülbelül 8 éves koruk után már kezdenek kételkedni a reklámok hitelességében. A hatodikosok esetében a tanulók 12\%-a azt állítja, hogy hisz a hirdetőknek. Ez az arány a harmadára csökken a tizenhat éveseknél. (Sas, 2007).

Más vizsgálat esetében arra a következtetésre jutottak a felmérést végzők, hogy nincs számottevő különbség a televízió és az internet között a reklámhatások (felidézés és felismerés javulása) szempontjából. A márkaépítésre gyakran használt fizetett online eszközök ugyanolyan mértékben bizonyultak hatékonynak, mint a televíziós reklámok (Bauer-Kolos, 2016).

\section{Anyag és módszer}

Primer kutatásunkat kvalitatív felméréssel végeztük, ezen belül is a kis fókuszcsoportos megkérdezést választottuk. A gyerekeket életkoruk szerint 3 csoportba soroltuk. Az egyik csoportot a 8-10 éves korosztály (4.-5. osztályosok) a 
másik csoportot a 10-14 éves korosztály (6.-8. osztályosok) míg a harmadik csoportot a 15-18 évesek (9-12. osztályosok) alkották. A legkisebbek és a legnagyobbak 5-5 fövel, a 10-14 évesek 6 fővel dolgoztak csapatban.

A feladatokat bevezető kérdésekkel kezdtük, ezzel felmérve a gyerekek csokoládéval, annak alapanyagával, származásával, kapcsolatos tudását. Továbbiakban játékos feladatokkal (márka-montázs, mondatok befejezése a saját véleményük szerint, reklámszlogen-márka párosítás, csokoládéval kapcsolatos reklámok, képek osztályozása és képek csoportosítása) folytattuk a közös munkát.

Sikerült megvalósítanunk azt a tervet, miszerint a gyerekek aktívan, kreatívan és segítőkészen fogjanak a feladatok megvalósításához. Ugyanakkor meg kell jegyeznünk, hogy ez a lelkesedés a 3. korcsoport esetében már nem volt jellemzö.

A fókuszcsoportos beszélgetések jó hangulatban a délutáni foglalkozás keretén belül, 2019 márciusában történtek. A kutatásról hangfelvétel készült, amelyhez a szülök beleegyezését kértük.

Jelent tanulmányunkban az első két korcsoport körében végzett eredményeket ismertetjük.

\section{Eredmények és értékelésük}

\subsection{A legfiatalabb csoport eredményei}

A fókuszcsoportos megkérdezést a 8-10 éves korosztályban kezdtük. 5 lelkes kisdiák dolgozott együtt, 1 lány és 4 fiú. A feszültség oldására néhány bevezető kérdést tettünk fel nekik, például, hogy fogyasztanak-e csokoládét, s amennyiben igen, milyen gyakran teszik. Egyöntetüen mindenkitől azt a választ kaptuk, hogy igen, ebböl ketten naponta, ketten hetente többször és egy diák mondta, hogy csak havonta néhány alkalommal.

A továbbiakban a csokoládéval kapcsolatos ismereteiket kívántuk feltárni. Kíváncsiak voltunk, ismerik-e a csokoládé legfőbb alkotóelemét, a kakaóbabot, rendelkeznek-e mélyebb tudással róla. A választ mindenki tudta, mint ahogy a kakaóbab színével, méretével is tisztában voltak, a származásáról azonban csak egy kisfiú tudott, aki már járt Dél-Amerikában és testközelböl is megismerkedhetett a növénnyel.

Érdekelt minket az is, hogy tisztában vannak-e egy tábla csokoládé átlagárával. Barbi adott jó választ, aki 200-300 forint körül tippelte az árat. Abban megegyeztek, hogy nagymértékben befolyásolja a csokoládé márkája az árát.

Rémlett nekik, hogy van Magyarországon csokoládégyár, azonban senki nem tudott megnevezni egyet sem, ezzel szemben a százalékos kakaótartalom jelét mindenki helyesen ismerte.

\section{Mapping módszer}

Megkértük a gyerekeket, hogy 14 csokoládé képét (Milka, Boci, Tibi, Kinder, Sport, Mars, Twix, Merci, Ferraro Rocher, Balaton, Stühmer, Kit Kat, Toffifee, 3Bit) valamilyen általuk meghatározott szempont szerint osszák fel két, majd, ha tudják, újabb két csoportra. Hosszas megbeszélés után a következő eredményre jutottak: 
- Töltött csokoládék: Ferrero Rocher, Toffiffee, Twix, Kinder csokoládé, Tibi csokoládé, Milka, Mars szelet, Merci

- Töltetlen: Stühmer, Boci, Balaton szelet, 3Bit, Kit Kat, Sport szelet

A tovább csoportosításnál nem jutottak közös nevezöre a gyerekek, így nem hoztak létre újabb két csoportot.

\section{Mondat-kiegészités technika}

A gyerekeknek az alábbi mondatokat kellett befejezniük, saját véleményük szerint:

„Akkor eszem csokoládét amikor..."

Ábel: ,... kedvem szottyan.”

Barbi: „,...amikor megéhezek rá.”

Bálint: ,, ...amikor nincs otthon ebéd és éhes vagyok.”

Milán: „,...amikor megkívánom.”

Zétény: „,...amikor édességre vágyom. '

$\mathrm{Az}$ első mondat kiegészítése során kiderült, hogy bármikor hozzáférhetnek a csokoládéhoz.

„Ha sok csokoládét eszem, akkor..."

Ábel: ,, ...tönkremennek a fogaim.",

Barbi: „...fájni fog a hasam.”

Bálint: , ,...menni fog a hasam.”

Milán: „... beteg leszek.”

Zétény: , ...elromlanak a fogaim."

A gyerekek tehát a sok csokoládé-fogyasztással kapcsolatosan kivétel nélkül negatívan asszociáltak, betegségekre utaltak.

„Ha nem lenne a világon csokoládé, akkor..."

Ábel: „,...nem is tudom igazán mi történne akkor."

Barbi: „, ...kitörne a háború.”

Bálint: ,, ...nem hiányozna, mivel nem tudnánk, hogy létezik. ”

Milán: „,...akkor kakaópor sem lenne.”

Zétény: , ,... sok élelmiszert hiányolnék."

Következtetéseik változatosak, egyéni sajátosságaikat, tájékozottságukat és logikájukat tükrözi.

\section{Buborékrajz módszer}

Egy csokoládét fogyasztó ember képét tettük ki az asztalra, akinek a feje mellett gondolatbuborékok voltak. A csoport feladata a szituációt átélő személy gondolatait, érzéseit beírni a buborékokba saját véleményük szerint. Az eredményt az 1. ábra mutatja. A gyerekek az alábbi szövegeket fogalmazták meg:

- Legközelebb is veszek ilyet

- Végre csokit is ehetek!

- Nagyon finom

- Ez a kedvencem, ez a kedvenc márkám

- De finom! 
1. ábra: Buborékrajz módszer a legkisebbek kiegészítése alapján

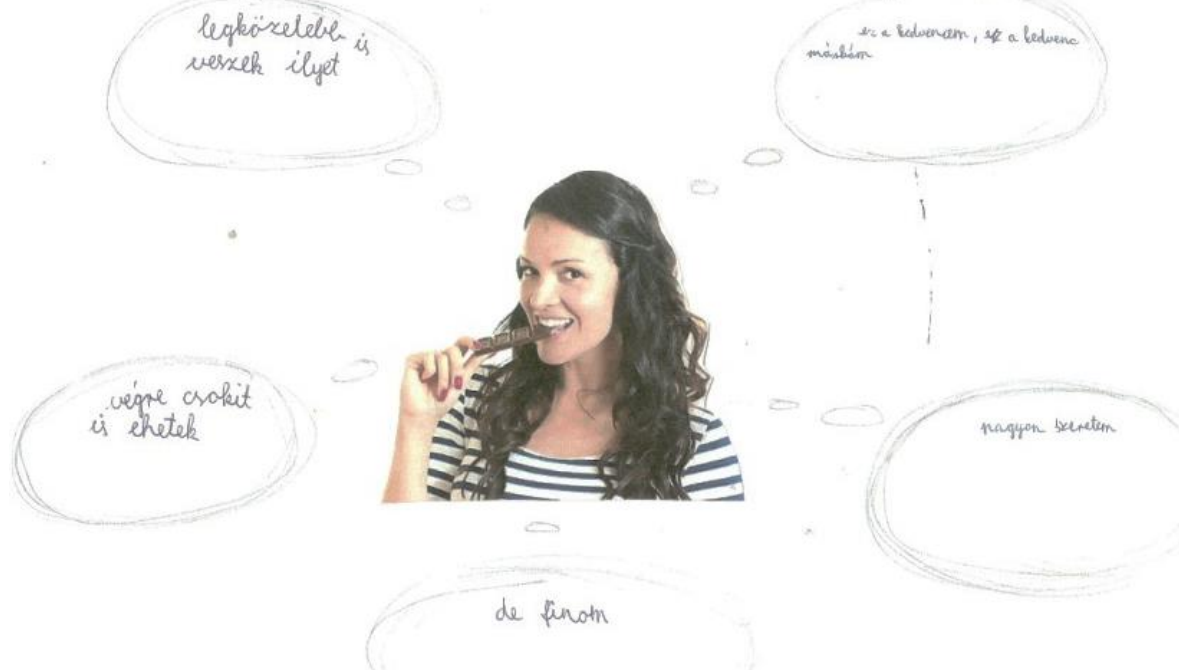

Forrás: Forró felvétele (2019)

\section{Márka-montázs}

Megkértük a gyerekeket, hogy magazinokból, újságokból kivágott képek közül válasszák ki azokat, amelyek a legjobban illenek a „csokoládé” szóhoz. Az eredményt a 2. ábra szemlélteti.

A kakaóbab és a mogyoró képe elsőként került a lapra, ami nem is annyira lehet meglepő, mivel ketten is a mogyorós csokoládét preferálják. A csokoládé nyusziról a húsvét és a locsolkodás jutott eszükbe a fiúknak. A Milka csoki, mint közkedvelt márka került a papírra. A rossz fogakra a sok édesség és csokoládéfogyasztásra következtettek.

\section{2. ábra: A gyerekek által készített montázs}

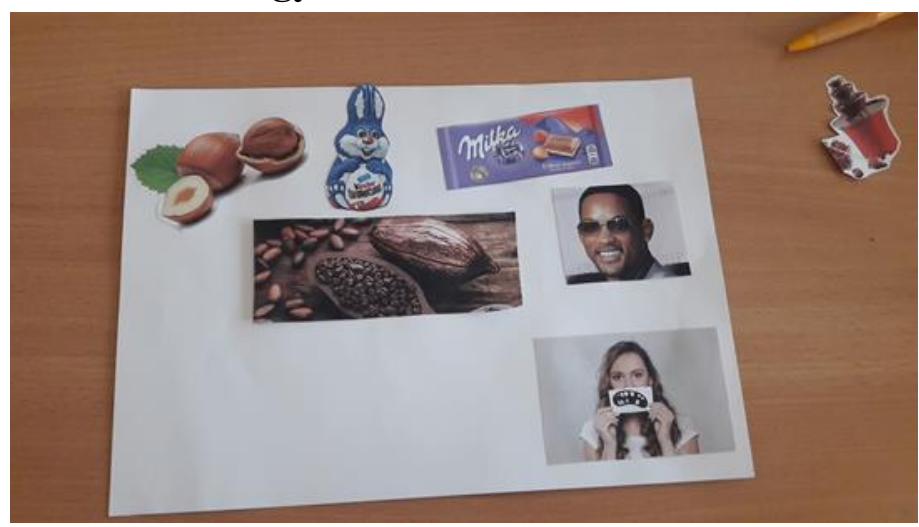

Forrás: Forró felvétele (2019) 


\section{Párositás}

Itt a gyerekek feladata az volt, hogy a csokoládé márkákhoz a reklámokban elhangzó szlogeneket társítsák.

Ki vagy ha éhes vagy? (Snickers)

Köszönöm, hogy vagy nekem. (Merci)

Az édenkert ize. (Bounty)

Merj gyengéd lenni. (Milka)

Bearanyozza a mindennapokat. (Ferrero Rocher)

Többet mond minden szónál. (Raffaello)

Ha kell egy kis energia. (Sport szelet)

Könnyü szívvel. (Kinder Bueno)

Elsőként a Snickers márka került a megfelelő szlogenhez, ami véleményünk szerint nem véletlen, mert ötletes, rövid, könnyen megjegyezhetö, szlenget is tartalmaz, és sokat hallják. Majd a mindenki által ismert Merci csokoládé, illetve a Ferrero Rocher következett. Ez utóbbinál az arany színủ csomagolása miatt következtettek a szlogenre. Ezek után a Sport szelet és a Raffaello szlogen-márka párosítás jött sorra. A legnagyobb fejtörést a Milka, a Kinder Bueno és a Bounty márkákhoz tartozó megfelelő szlogen okozta, amit némi segítséggel sikerült megoldani. Úgy véljük, azért ez a három márka maradt a végére, mert ezek régebbi szlogenek, amit a gyerekek még nem láthattak fiatal koruk miatt.

A fenti eredmények azt igazolják, hogy fontos a több csatornán, több érzékszervre ható hatás: jó szlogen, figyelemfelhívó színek, képek, fülbemászó zene.

\section{Megszemélyesités}

Utolsó feladatként megkértük a gyerekeket, hogy képzeljenek el egy olyan személyt, aki még sosem, és egy olyat, aki szinte mindig csokoládét fogyaszt, és írják le ezt a két embert. A gyerekek az alábbi tulajdonságokat sorolták fel: egy 28 éves nő, kék szemü, hosszú szőke hajú, és nagyon vékony, kecses, emellett mindig vidám, jókedvü. A második típuskén egy 45 év körüli, kövér, kopaszodó férfi, került leírásra, hiányos és rossz fogakkal, mogorva, magányos és magának való.

Ebböl a feladatból is lehet következtetni arra, hogy sok negatív tulajdonsággal ruházták fel a rendszeres csokoládé-fogyasztó személyt.

\subsection{A 10-14 évesek vizsgálati eredményei}

A fókuszcsoportos megkérdezést a 10-14 éves korosztályban, tehát a 6.-8. osztályosok körében folytattuk. Ebben a korosztályban 6 tanuló volt a segítségünkre, 2 fiú és 4 lány. Hamar kiderült, hogy Barnabás a laktózérzékeny kisfiún kívül mindenki szokott csokoládét fogyasztani. Heti 1-2 alkalomtól kezdve akár a napi szintü csoki-fogyasztásig minden képviselő jelen volt. A csokoládé alkotóelemeiről is hasznos tudással rendelkeztek a gyerekek. A kakaóbab kinézetével is többnyire tisztában voltak, a kávészemhez hasonlították. Származásáról nem volt információjuk, a kakaóporról Hollandiára következtettek. Korukból adódóan tisztában voltak egy tába csokoládé átlagárával, így 280 forintot tippeltek. A csokoládék árát véleményük szerint a csokoládé minősége és a gyártó befolyásolja 
leginkább. Biztosak voltak abban, hogy van az országunkban csokoládégyár, azonban csak Barnabásnak jutott eszébe a Szerencsen található gyár neve. A csokoládékon található \% jelről mindenki tudta, hogy a kakaótartalmat jelöli.

A mapping módszernél az alábbi két csoportot különböztették meg:

- Szeletes csokoládék: Mars, Balaton, Sport, 3Bit, Twix, Kinder, Merci, Kit Kat

- Nem szeletes csokoládék: Boci, Stühmer, Milka, Tibi, Toffifee, Ferraro Rocher)

Sajnos ennek a korosztálynak sem volt ötlete a további csoportokra bontáshoz.

A mondatok kiegészítése során az alábbi eredmények születtek: „Akkor eszem csokoládét amikor..."

Hanna: , ,...megéhezem rá.”

Kamilló: „,...amikor van otthon."

Ninett: , ,...amikor kedvem van hozzá”

Petra: , ....amikor van otthon."

Zsanett: „...édességre vagyok éhes.”

Elég nehéznek bizonyult ez a kérdés a korosztály számára, nehezen születtek a válaszok, egymás ötleteiből merítettek a gyerekek.

„Ha sok csokoládét eszem, akkor..."

Hanna: , ,...rosszul leszek.”

Kamilló: , ,...elhizok”

Ninett: „,...nem férek a ruháimba."

Petra: , ,...tönkremennek a fogaim. ,

Zsanett: „,...hányingerem lesz.”

A válaszaikból arra következtetek, hogy ez a korosztály is a mértéktelen csokoládé- fogyasztás egészségre káros hatásait emelte ki.

„Ha nem lenne a világon csokoládé, akkor..."

Hanna: , ,...akkor nem tudnánk, hogy létezik, így nem is hiányozna.”

Kamilló: „, ... nem is tudom mit nassolnék.”

Ninett: „,...nem lenne boldogsághormon."

Petra: „,...szomorú lennék. ”

Zsanett: , ,...nem lennének fogorvosok.”

A kérdésre adott reakciók változatosak, a feladat megmozgatta a gyerekek fantáziáját.

A buborékrajz-módszernél humorosabb megjegyzések születtek, mint a kisebb gyerekek esetében (3. ábra)

- Nem is szoktam csokievés közben mosolyogni

- Csak a reklám kedvéért eszem ezt a csokit

- Kérek még!

- Miért nem adtak többet?

- Ízletes! 


\section{3. ábra: A 10-14 évesek által készített buborékrajz}

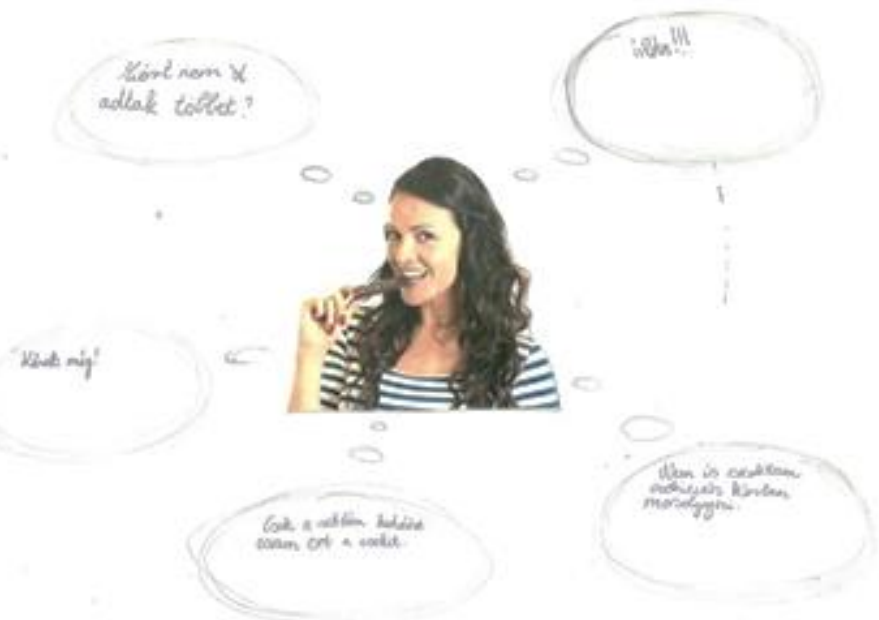

Forrás: Forró felvétele (2019)

Kreativitásuk a montázs esetében is megjelent. A 4. ábrán bemutatott képen két folyamat látható. Az elsőn a sok csokoládé miatti fogromlás jelensége tükröződik vissza, míg alatta az elhízás veszélyére hívták fel a figyelmet a gyerekek.

\section{4. ábra: Montázs-kép (10-14 évesek)}

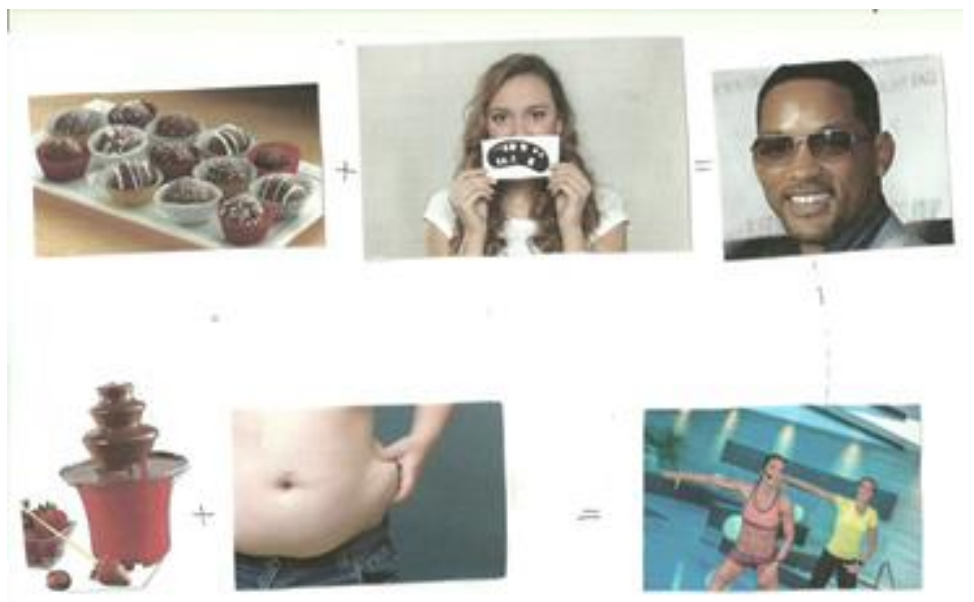

Forrás: Forró felvétele (2019)

A párosító játéknál elsők között a Merci, a Ferrero Rocher és a Snickers márka találta meg hozzá tartozó szlogent. A Raffaellot és a Sport szelet ikonikus mondataira is rögtön ráismertek a gyerekek. A Milka, Bounty és a Kinder Bueno szlogenjei maradtak utoljára, ám még így is helytelenül párosították a márkákhoz, míg végül feladták, és tőlünk várták a helyes megoldást.

Végzetül a megszemélyesítéssel zártuk számukra is a feladatokat. A gyerekek véleménye szerint, aki még soha nem fogyasztott csokoládét egyértelmüen vékony, fiatal nő, szép fogsorral. Mindig ingerült, stresszes és szomorú. A tanulók az alábbi 
módon írták le azt a személyt, aki mindig csokoládét fogyaszt: egy 16 év körüli túlsúlyos fiú, aki folyamatosan fogorvoshoz jár, a rossz fogai miatt. Az iskolában rosszul teljesít, ami annyira nem zavarja, nyugodt, jókedvű személyiség.

\section{Következtetések}

A fókuszcsoportos vizsgálatok során - bár 3 korosztályt vizsgáltunk, tanulmányunkban csak kettőt mutattunk be. Jellemzően ök mutattak kellő aktivitást a feladatok megoldásában.

Úgy látjuk, a mai gyerekek igen jól informáltak, széles látókörüek, tisztában vannak a reklámozott termékek káros hatásaival, bár ezen információkat valószínüleg a szülőktől, vagy az iskolai tanulmányaik során nyerik.

A reklámokra való emlékezést a szlogenek kapcsán mutattuk be, érdekes módon más-más mondatokra emlékeztek a különbözö korosztályba tartozó gyerekek.

Természetesen a kvalitatív kutatás csupán egy alap, melyre egy kvantitatív felméréssel lehet tovább építkezni. és újabb információhoz jutni.

\section{Irodalomjegyzék}

Agárdi I. (2010): Kereskedelmi marketing és menedzsment. Akadémiai Kiadó, Budapest.

Bauer A., Berács J., Kenesei Zs. (2014): Marketing alapismeretek. Akadémiai Kiadó, Budapest.

Bauer A., Kolos K. (2016): Márkamenedzsment. Akadémiai Kiadó, Budapest.

Coady, Ch. (2008): Csokoládé. Gabo Könyvkiadó, Budapest.

Gyimes E., Szabó P. B. (2008): Istenek eledele, a kakaó. Édesipar 54 (1-2): 5-8.

Kovács L., Csupor D., Lente G., Gunda T. (2011): Száz kémiai mítosz. Akadémiai Kiadó, Budapest. Sas I. (2007): Reklám és pszichológia. Kommunikációs Akadémia, Budapest:

<https://hogyanmondjamelneked.hu/gyereked-vilaga/2017/10/31/mennyi-idot-toltenek-a-gyerekek-

kepernyo-elott> (2019.04.11.)

<http://szerencsibonbon.hu/cegunkrol/> (2019.08.02.)

<http://www.bonbonetti.hu/a-bonbonetti/> (2019.08.02.)

$<$ https://www.origo.hu/techbazis/20181001-magyarorszag-tevenezesi-ido-streaming-szolgaltataselterjedtseg.html> (2019.03.10.)

<http://www.stuhmer.hu/hu/stuhmer> (2019.08.02.) 